\title{
Implementasi Pendidikan Karakter dalam Pembentukan Sikap Sosial Kebangsaan Peserta Didik melalui Pembelajaran IPS (Studi Literatur)
}

\author{
Reni Novita Sari ${ }^{\text {a, } 1}$, Ayu Citra Resmi ${ }^{\text {a,2 }}$ \\ ${ }^{a}$ Reni Novita Sari, Novitareni887@gmail.com \\ ${ }^{a}$ Ayu Citra Resmi, ayucitra1706@gmail.com
}

\begin{tabular}{ll}
\hline & ABSTRACT \\
\hline Kata kunci: & Pendidikan karakter diperlukan untuk membentuk sebuah sikap, kepribadian dan moral \\
Pendidikan & suatu bangsa. dalam penerapanya pendidikan karakter bisa diterapkan melalui proses \\
parakter, & ini bertujuan untuk mengetahui peranan pembelajaran Ilmu pengetahuan sosisl dalam \\
Sosial & pembentukan Karakter peserta didik serta untuk mengetahui penerapan atau implementasi \\
Pembelajaran IPS & pendidikan karakter dalam pembelajaran ilmu pengetahuan sosial. Metode penelitian ini \\
& menggunakan metode peneliti literatur, penelitian kajian literatur dengan mencari referensi \\
& teori yang relevan dengan kasus atau permasalahan yang ditemukan. Hasil penelitian ini \\
& adalah pendidik atau guru dan sekolah berperan penting dalam pembentukan karakter \\
& peserta didik melalui aturan sekolah, kegiatan yang diikuti maupun dalam proses \\
& pembelajaran. Pendidikan karakter di terapan pada peserta didik melalui pembelajaran Ilmu \\
& Pengetahuan sosial diseduaikan dengan materi dan kondisi peserta didik. Metode \\
& pembelajaran dan pemahaman guru tentang materi juga berpengaruh terhadap \\
& pengembangan pendidikan karakter. Dalam pembelajaran Ilmu Pengetahuan Soial juga \\
memiliki tujuan yang sama dengan pendidikan karakter yaitu untuk menciptakan warga & \\
& negara yang baik dan memiliki nilai-nilai moral. .
\end{tabular}

\begin{tabular}{ll}
\hline & ABSTRAK \\
\hline Keyword: & Character education is needed to form atitude, personality and morals of a nation. \\
Character & In its application character education can be applied through the learning process \\
building, & one of which is in learning ocial science. The study aims to determine the role of \\
Social, & social science in the formation of learners character and to know the application or \\
IPS learning & implementation of character education in social science. This reseach method uses \\
& literatur, literatur research metodhs theough various agreed procedures. The \\
& results of this study are educators or teachers and schools play an important role in \\
& shaping the character of students through schools rules, activitiesthat are followed \\
& and learning process. Character education is applied to students through social \\
& science tailored to the material and conditions of students. Leraning methods and \\
& teacher understanding of the material also affect the development of character \\
& education. In learning social science also has the same goal as character education \\
& which is to create good citizens and have moral values.
\end{tabular}

Copyright $\odot$ 2020Tadris IPS Institut Agama Islam Negeri Kudus. All RightReserved

\section{Pendahuluan}

Perkembangan teknologi dan komunikasi pada saat ini mengakibatkan dampaknya di masyarakat salah satunya kepribadian dan moral individu. Arus globalisasi memberikan dampak negatif salah satunya di kalangan Remaja atau generasi muda. Karakter atau kepribadian bangsa indonesia yang menjadi ciri khas sendiri yang terkenal santun, ramah dan

perduli sesama seakan punah dan tergeser menjadi karakter yang negatif. Untuk membentuk siswa yang baik dibutuhkan pembentukan karakter dalam lembaga 
pendidikan. Dalam dunia pendidikan sendiri mendidik generasi muda dan mendidik anak untuk menjadi kepribadian yang baik namun sekarang bayak periaku yang menyimpang yeng terjadi di lingkungan pendidikan. Pendidikan atau mendidik tidak hanya mentransfer ilmu saja, namun pendidikan juga dpat mengubah karakter dan watak sesorang agar menjadi lebih baik, lebih sopan dalam tatanan etika maupun estetika maupun perilaku dalam kehidupan sehari-hari (asep jihad, muchlas rawi, 2010:47).

Pendidikan karakter menurut kusuma merupakan nilai-nilai dasar yang harus dihayati jika sebuah masyarakat mau hidup dan bekerja sama secara damai. Nilai-nilai seperi kebijaksanaan, penghormataan terhadap yang lain tanggung jawab pribadi, perasaan senasib, sependeritaan, pemecahan konflik secara damai, merupakan nilai-nilai yang semestinya diutamakan dalam pendidikan karakter (kusuma, 2007:250). pendidikan karakter merupakan sebuah wadah untuk membuat kepribadian generasi muda agar tidak melenceng dengan norma dan nilai yang berlaku. Pendidikan sendiri merupakan sebuah lembaga untuk mengubah atau membentuk sebuah karakter dan kepribadian seseorang agar lebih baik lagi. Sedangkan menurut Doni Koesuma (Narwanti, 2014:79) pendidikan karakter adalah sekolah, Semua pihak yang terlibat di dalam sekolah memiliki tanggung jawab membangun pendidikan karakter. Walupun befitu pendidikan karakter merupakan proses keseluruhan dalam proses pendidikan yang dialami oleh peserta didik sebagai pengalaman dalam pembentuk kepribadian memulai memahami dan mengalami sendiri nilai-nilai, keutamaan moral, agama, norma dan sebagainya. Dalam hal itu lingkungan sekolah sangat berperan terhadap pendidikan karakter, peran guru, orang tua, masyarakat sekitar dan negara tidak kalah penting.

Pendidikan karakter itu sendiri bertujuan untuk meingkatkan sebuah mutu hasil pendidikan yang mengarah pada pembentukan karakter dan akhlak mulia seorang peserta didik secara utuh, terpadu dan seimbang sesuai dengan yang ada di standar kompetensi kelulusan. Melalui sebuah pendidikan karakter pesrta didik diharapkan mampu secara mandiri untuk dapat meingkatkan dan menggunakan ilmu pengetahuanya dalam mengkaji dan mengintegrasikan nilai-nilai pendidikan karakter dan akhlak mulai yang terwujud dalam perilaku sehari-hari. Sedangkan tujuan utama pendidikan karakter adalah menfasilitasi penguatan dan pengembangan suatu nilai-nilai tertentu sehingga terwujud dalam sebuah perilaku anak, baik dalam proses sekolah. Penguatan dan pengembangan sendiri memiliki makna bahwa dalam pendidikan seting sekolah bukan hanya sekedar mendapatkan nilai kepada peserta didik, tetapi juga sebuah proses membawa peserta didik untuk memahami dan menggunakan bagaimana suatu nilai tersebut menjadi penting sehingga dapat diwujudkan dalam perilaku sehari-hari (kusuma, 2007: 9).

Pembelajaran dalam pendidikan karakter penulis mendefinisikan sebagai pembelajaran yang mengarah pada penguatan dan pengembangan perilaku anak secara utuh yang didasarkan atau dirujuk pada suatu nilai. Penguatan adalah upaya untuk melapisi suatu perilaku anak sehingga berlapis atau kuat (kusuma, 2007: 110). Dalam hal ini pengembangan perilaku merupakan sebuah adaptasi sebuah perilaku anak terhadap situasi maupun kondisi baru yang dihadapi berdasarkan pengalaman yang anak dapatkan. Proses pengembangan karakter dan proses pengembangan kemampuan akdemik peserta didik dijalankan secara bersamaan. Dalam hal ini guru merancang proses pembelajaran yang sekreatif mungkin sehingga setiap mata pelajaran dapat menjadikan sebuah wahana untuk mengembangkan sebuah karakter.

Mata pelajaran IPS atau sosial studies yang lebih kmprehensif dirumuskan oleh National Commission on the Social Studies (NCSS) bahwa studi sosial adalah subjek yang 
berdasarkan pada suatu kurikulum yang memiliki tujuan untuk mengembangkan warga dalam suatu negara untuk menjadi yang lebih baik dalam suatu masyarakat demokratis yang berhubungan dengan suatu bangsa atau masyarakat di dunia lainya: yang berisi materi dari sejarah, ilmu-ilmu sosial lainya, serta ada yang berasal dari humaniora dan ilmu pengetahuan: yang diajarkan kepada peserta didik berasal dari pemikiran atau pengalaman pribadi, sosial dan budaya sesuai dengan perkembangan yang dicapai peserta didik, serta mentransfer apa yang di dapat dari sekolah dengan kehidupan sehari-hari atau kehidupan nyata di masyarakat (Pranomo, 2013:11). pembahasan yang disajikan dalam pelajaran IPS bukan hanya pengetahuan tentang materi namun juga meliputi nilai-nilai yang ada dalam sikap dan diri peserta didik. Guru juga harus mampu menciptakan kondisi pembelajaran maupun mengrahkan peserta didik ke hal-hal yang positif karena guru merupakan panutan atau perantara untuk menciptakan karakter atau kepribadian kepada peserta didik.

Menurut Gross dan kawan-kawan telah mengidentifikasi dua tujuan utama pendidikan IPS yaitu mempersiapkan peserta didik nntuk menjadi seorang warga negara yang berguna dengan baik dalam masyarakat demokratis dan membantu siswa dalam membuat keputusan yang rasional tentang masyarakat dan masalah-masalah sosial. Tujuan pendidikan IPS diarahkan pada pembentukan sikap dan pembentukan kepribadian serta peningkatan penguasaan pengetahuan dan keterampilan yang dimiliki peserta didik (Pranomo, 2013:13). pembelajaran IPS sejak dulu dituntut untuk mencapai pembentukan karakter dan kepribadian bukan hanya transfer ilmu saja kepada peserta didik. Pembelajaran IPS bukan hanya membentuk kepriadian peserta didik namun juga mencerminkan kesadaran kepribadian masyarakat dan pengalaman budaya yang ada. Pembelajaran IPS juga akan lebih bermakna dan dapat dipahami peserta didik apabila yang diajarkan berdasarkan pengalaman budaya dan perkembangan mental peserta didik yang ada. Jadi pendidikan ips memberikan kontribusi yang besar dalam pembentukan karakter peserta didik.

\section{Metode}

Penelitian ini termasuk jenis penelitian kajian literatur dengan mencari referensi teori yang relevan dengan kasus atau permasalahan yang ditemukan. Menurut Creswell John dalam jurnal Bakhrudin, menyatakan bahwa kejian literratur adalah ringkasan tertulis mengenai artikel dari jurnal, buku dan dokumen lain yang mendeskripsikan teori secara informasi baik tersebut dalam masa lampau maupun pada saat ini yang mengorganisasikan pustaka ke dalam topik dan dokumen yang dibutuhkan (Habsy, 2017:92).

Langkah-langkah yang digunakan dalam studi Literatur diantaranya pengumpulan data pustaka, membaca dan mencatat, serta membandingkan literatur untuk kemudian diolah dan dijadikan sebuah kesimpulan. Data yang digunakan merupakan data sekunder yang berasal dari texbook, jurnal, artikel ilmiah, literarut riview merupakan tentang konsep yang diteliti (Wulandari \& Vebrianto, 2017:711). Dengan rencana penelitian menggunakan tahapan-tahapan sebagai berikut:

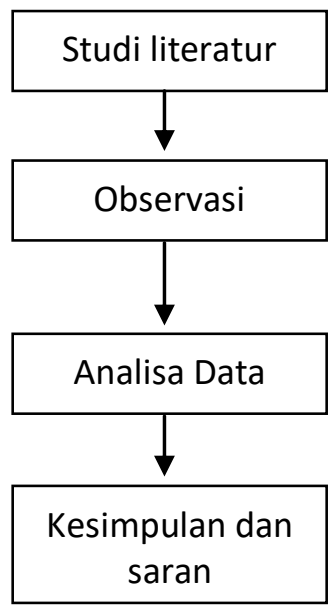

Gambar 1.0 Rencana Penelitian 
Studi literatur dilakukan yakni dengan cara mengumpulkan data dan mempelajari penerapan dari data beberapa jurnal penelitian yang sudah dikumpulkan. Observasi atau pengamatan dilakukan dari hasil jurnal yang dikumpulkan. Melakukan analisa pengembangan media pembelajaran dari hasil data yang dikumpulkan sehingga dapat menarik kesimpulan (Nadziroh, 2017: 5).

\section{Hasil dan pembahasan}

1. Peran pembelajaran IPS dalam pembentukan sikap sosial peserta didik

Pembelajaran IPS memiliki sangat peran strategis dalam pembentukan karakter peserta didik. Dalam pendidikan karakter dapat dimaknai sebagai pendidikan nilai, pendidikan moral maupun pendidikan bukti pekerti. Pendidikan karakter itu sendiri memiliki arah dan tujuan yang telah sama dengan tujuan pembelajaran IPS, yaitu sama-sama bertujuan agar peserta didik dapat menjadi warga negara yang baik (Darmadi, 2007:8).

Pembangunan karakter sebuah bangsa merupakan sebuah gagasan yang dicetuskan oleh para pendiri bangsa itu sendiri. Pemerintah merupakan sebuah wahana pembentukan karakter melalui keteladanan dalam penyelenggaraan negara, elit pemerintah dan elit politik. Pemerintah saat ini merupakan komponen yang penting dalam proses pembentukan karakter bangsa karena aparatur negara sebagai penyelenggara pemerintah merupakan pengambil dan pelaksana kebijakan yang ada di suatu negara. Dengan adanya pendidikan karakter dapat membantu peserta didik untuk menjadikan kepribadian yang lebih baik lagi. Dalam pembelajaran IPS diarahkan dalam pembentukan sikap dan memiliki kepribadian yang profesional serta peningkatan penguasaan pengetahuan dalam keterampilan peserta didik. Dalam mencapai tujuan pembelajaran ips sebagai implementasi dari pendidikan IPS dilaksanakan dengan orientasi untuk mencapai tujuan pendidikan. Cakupan materi di sekolah atau pembelajaran disusun dengan berdasarkan materi keterampilan, pengetahuan dan sikap. Dimana nanti ketentuan-ketentuan tersebut harus dicapai oleh peserta didik untuk di implementasikan dalam kehidupan seharihari.

Pendidikan karakter dan ilmu pengetahuan sosial memiliki kesamaan tujuan yaitu dengan membentuk peserta didik untuk menjadi warga negara yang baik. Dalam hal ini Ips sendiri memiliki peran penting dalam pembentukan karakter terhadap peserta didik. Peserta didik diharapkan mampu perduli dengan permasalahan-permasalahan sosial, pembentukan sikap sosial di masyarakat, serta memiliki rasa kebangsaan yang tinggi. Ips saat ini menjadi sebuah fondasi penting bagi perkembangan intelektual anak, emosionl, budaya dan sosial perserta didik itu sendiri dengan mampu menumbuhkan cara berfikir, sikap dan perilaku yang memiliki tanggung jawab selaku individual, warga masyarakat dan warga negara yang baik. Selain hal tersebut pembelajaran Ips juga mampu mengembangkan potensi peserta didik agar dapat peka terhadap suatu permasalahan sosial yang ada di masyarakat sekitar, yang mana mampu menjadikan peserta didik mengatasi permasalahan yang terjadi sehari-hari yang ada dalam dirinya maupun masyarakat sekitar.

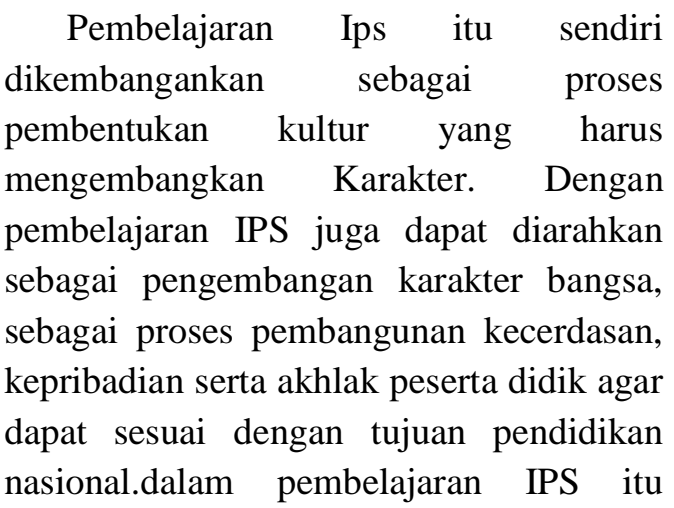


sendiri harus sesuai dengan konseptualnya terpadu yang menekankan pada sebuah interdisipliner dan transdisipliner dalam pembelajaran yang kontekstual dan transformatif serta aktif dalam aksi sosial kemasyarakatan. Pembelajaran IPS harus menfokuskan pada peranya untuk mengembangkan karakter peserta didik untuk menjamin kelangsungan hidup yang ada di masyarakat sekitar.

Pedidikan IPS sangat banyak berperan dalam mewujudkan karakteristik siswa yang belandaskan kepada moral yang baik serta serta dapat juga dilaksanakan dalam kehidupan sehari-harinya sebagai makhluk sosial. Pendidikan IPS yang di pandang berhasil di masyarakat dalam membantu membentuk perilaku peserta didik dalam membangun moral bangsa itu sendiri. Menurut lickona dalam joseph (2010) mengatakan bahwa pendidikan karakter di sekolah dapat juga berjalan sebagaimana mestinya, setia peserta didik bukan hanya berkembang dalam konteks moral saja atau karakter saja namun juga berdampak pada kehidupan sosial mereka. Jika program pendidikan yang ada di sekolah mengembangkan kualitas antara guru dan peserta didik, serta hubungan antara peserta didik dan orang lain, mka hal tersebut tidak langsung akan tercipta lingkungan yang baik untuk belajar dan mengajar. Pembelajran ips di arahkan agar dapat melahirkan perilaku-perilaku sosial yang berdimensi personal misalnya: berbudi luhur, disiplin, kerja keras, dan mandiri. Dalam dimensi struktural: cinta tanah air, menghargai dan melestarikan karya budaya sendiri, mengembangkan semangat kebangsaan, dan keperdulian lingkungan dan sosialnya). Terdapat tiga kompetensi dalam pembelajaran IPS yang dapat kalian ketahui seperti kompetensi personal, kompetensi sosial, dan kompetensi intelektual.

a. Kompetensi personal

Merupakan suatu kemampuan dasar yang berkaitan dengan pembentukan dan pengembangan kepribadian diri oleh peserta didik sebagai makhluk individu yang merupakan sebuah hak dan tanggung jawab personalnya. Sejumlah kompetensi personal yang terdapat dalam pembelajaran IPS misalnya pembentukan konsep, sikap objektif, disiplin, kerja keras, kreatifitas diri, dll.

b. Kompetensi sosial

Kemampuan dasar yang berkaitan dalam yang berkaitan dengan sebuah pengembangan kesadaran sebagai makhluk sosial dan makhluk yang tidak dapat hidup sendiri. Sebuah kompetensi dasar yang dikembangkan yaitu kesadaran dirinya sebagai anggota masyarakat sehingga perlu menghargai dan memahami satu sama lain, kesadaran dan pemahaman atau kesatuan dalam hidup bermasyarakat berbangsa dan bernegara, kemampuan berkomunikasi dan bekerja sama.

c. Kemampuan intelektual

Kemampuan berfikir yang didasarkan pada adanya kesadaran atau keyakinan atas semua yang baik yang bersifat fisik, sosial dan psikologi. Kemampuan yang dikembangkan yaitu pengembangan jati diri peserta didik dalam membangun pengetahuan, nilai, dan sikap sebagai makhluk sosial (Anshori, 2016: 72-73).

2. Implementasi pendidikan karakte

Pedidikan merupakan sebuah tulang punggung suatu strategi pembentukan sikap dan karakter bangsa. Strategi dalam pembangunan karakter bangsa melalui pendidikan juga bisa dilakukan pendidikan, pembelajaran dan fasilitas yang mendukung. Penerapan pendidikan karakter yang paling efektif dan strategis untuk mewujudkan pendidikan karakter 
yang diharapkan dengan melaui dunia pendidikan sejak Dini yaitu sejak Paud sampai jenjang perguruan tinggi. Seorang guru dan karyawan dalam suatu sekolah dituntuk untuk lebih berkomitemn lagi dalam pembentukan karakter peserta didik. Bukan hanya memberikan pemahaman dan pembelajaran tetapi juga memberika contoh yang baik kepada peserta didik (Guswantoro et al., 2018:111).

Sekolah sebagai wadah dalam pembentukan karakter dapat menggunakan strategi pembentukan karakter dengan pembinaan dan pengembangan karakter menguunakan:

a. Pendekatan Integrasi dalam semua mata pelajaran.

b. Pengembangan budaya suatu pendidikan.

c. Pelaksanaan kegiatan kokulikuler dan ekstrakulikuler.

d. Pembiasaan perilaku dalam kehidupan di lingkungan suatu pendidikan maupun lingkungn masayarakat.

Kunci dari keberhasilan pengembangan program pendidikan karakter pada suatu pendidikan adalah keteladanan para pendidik dan tenga pendidik maupun dukungan dari sekolah itu sendiri. Penerapan suatu keteladanan di lingkungan pendidikan menjadi sebuah persyaratan dalam pembentukan karakter peserta didik (Narwanti, 2014).

Pembelajaran IPS merupakan sebuah program pendidikan dapat membantu mengembangkan pengetahuan, keterampilan dan sikap yang dibutuhkan oleh peserta didik untuk dapat melaksanakan pemecahan masalah, penyelidikan, membuat keputusan, dan berperan serta dalam lehidupan masyarakat. Dapat dilihat beberapa ciri pendidikan IPS sebagai berikut:

a. Ips sebagai program pendidikan atau mata pelajaran dalam kurikulum sekolah yang di adaptasi dari Sosial Studies. b. Ipa sebagai program pendidikan saat ini berusaha mengkaji suatu masalahmasalah kehidupan masyarakat, bangsa dan negara secara Rinci.

c. Ips sebagai program pendidikan dalam suatu kurikulum sekolah yang di adaptasi dari citizenship dan civic education.

d. IPS sebagai civic education berusaha membentuk peserta didik agar dapat menjadi warga negara yang lebih baik (good citizen) dan mampu berperilaku serta secara aktif berperan di masyarakat yang demokratis.

e. IPS sebagai program pendidikan bukan hanya mencakup ilmu sosial yang di sederhanakan untuk kepentingan pendidikan di sekolah melainkan mencakup pendidikan nilai atau etika, filsafat, agama dan humaniora.

f. Ips sebagai program pendidikan berusaha untuk meningkatkan wawasan dan penguasaan pengetahuan dan keterampilan fungsional serta pengembangan sikap dan kepribadian profesional peserta didik.

g. Ips sebagai program pendidikan berusaha membekali peserta didik agar memiliki kemampuan dalam memahami dan memecahkan masalah-masalah kehidupan manusia.

h. Ips sebagai program pendidikan berusaha membekali peserta didik agar memiliki kemampuan dalam pengambilan keputusan secara tepat sesuai dengan permasalahan dn kebutuhan masyarakat, bangsa dan negara.

i. Ips sebagai program pendidikan mencakup komponen pengetahuan, sikap, dan keterampilan-keterampilan dasar seperti keterampilan berfikir, keterampilan melakukan penyelidikan, kemampuan akademik, dan keterampilan sosial sebagai dasar pembentuk negara yang baik 
memiliki kemampuan dalam pengambilan keputusan.

j. Pembelajaran IPS harus selalu di kaitkan dengan pendidikan nilai agar nantinya peserta didik sebagai warga negara yang baik memiliki kemampuan dalam pengambilan keputusan secara rasional dan objektif.

k. IPS menekankan pada model-model pembelajaran yang dapat melibatkan peserta didik secara aktif dalam kegiatan belajar mengajar (Pranomo, 2013: 28-29).

Dari ciri-ciri pendidikan IPS di atas banyak juga berkaitan dengan pendidikan karakter, bagaimana pendidikan karakter sampai kepada peserta didik dan dapat diterima dengan baik oleh peserta didik. Dengan adanya ciri-ciri dalam pendidikan IPS tersebut jika seorang pendidik mampu mengembangkan atau mengarahkan peserta didik dengan baik juga akan mempengaruhi pendidikan karakternya.

Saat proses pembelajaran guru mempertimbangkan dari beberapa hal diantaranya yaitu materi pembelajaran, merode pembelajaran, media pembelajaran dan aktivitas peserta didik dalam proses pembelajaran. Dalam implementasi pendidikan karakter dilakukan pendidik dengan cara salah satunya nilai-nilai karakter yang sesuai dengan apa yang ada di materi pembelajaran selama peserta didik melakukan pembelajaran atau penguasaan materi pembelajaran IPS. Dengan cara integrasi bertujuan untuk dapat tercapainya pembelajaran IPS, sementara itu penanaman nilsi-nilsi karakter juga dapat dilakukan secara lebih efektif. Sama halnya dengan hasil penelitian Ramandhani (Zuhud Ramdani, 2015: 113) bahwa dalam melaksanakan pembelajaran IPS materi ataupun bahan pembelajaran IPS tetap pada porsi yang telah ditetapkan dalam kurikulum, namun demikian dalam praktik pembelajaranya di sesuaikan atau di terapkan pendidikan karakter.

Implementasi atau penerapan yang dapat dilakukan oleh guru dalam menumbuhkan karakter siswa yaitu: menerapkan metode pembelajaran yng dapat melibatkan partisipasi aktif peserta didik, menciptakan lingkungan belajaran yang kondusif, memberikan pengajaran pendidikan karakter peserta didik, memmerhatikan keunikan dan potensi masing-masing siswa agar dapat dikembangkan dengan baik nantinyan (Anshori, 2016: 72-75).

Pendidikan karakter merupakan tugas pendidikan untuk mendampingi proses insiasi menjadi warga dunia. Materi pendidikan dan pembelajaran harus menanamkan nilai-nilai kemanusian dan mengembangkanya menjadi bernilai bagi sesama. diperlukan pembelajaran hidup dalam masyarakat malalui pembatinan dalam diri sendiri dan mengondisikan agar siswa mampu mengembangkan nilai kemanusiaan. Pendidikan karakter sebetulnya usaha individu siswa dalam berkembang dan menemukan maka lebih, nilai, semangat dan kecerdasan dan sikap dalam melakukan pembatasan diri di lingkungan sosial (tim sanggar pendidikan grasindo, 2010: 9). Pembelajaran ips sendiri sangat berpengaruh dalam kehidupan sosial anak, baik di lingkungan keluarga, sekolah dan masyarakat. Agar dapat berperilaku sesuai dengan norma-norma dan pertauran yang ada dan menciptakan bangsa yang mempunyai wibawa yang baik.

\section{Simpulan}

Pendidikan karakter sangat dibutuhkan dalam membentuk sikap, kepribadian dan moral anak, maka dari itu pemerintah 
mengharuskan pendidikan karakter untuk menciptakan kepribadian bangsa yang baik. Peranan Pembelajaran IPS dalam pembentukan sikap sosial peserta didik sendiri sangat berperan penting atau memiliki pengaruh penting. Pembentukan karakter dengan melalui pembelajaran IPS diharapkan nantinya peserta didik memiliki kepribadian atau sikap sesuai dengan yang diharapkan atau acuan pendidikan. Dengan adanya pendidikan karakter nanti pesertadiharapkan peserta didik mendapatkan kepribadian serta sikap sesuai ang diharapkan dan sesuai dengan ajaran Islam. Yang dimana nantinya bukan hanya berdasarkan nilai-nilai moral dan kebangsaan namun juga mengacu pada keimanan dan ketaqwaan sejalan dengan tujuan madrasah atau sekolah untuk menciptakan peserta didik sesui dengan karakter agama islam.

\section{Daftar Pustaka}

Anshori, S. (2016). KONTRIBUSI ILMU PENGETAHUAN SOSIAL DALAM PENDIDIKAN KARAKTER. Edueksos : Jurnal Pendidikan Sosial \& Ekonomi.

asep jihad, muchlas rawi, noer komarudin. (2010). pendidikan karakter teori dan aplikasi. rineka cipta.

Guswantoro, G., Rindrayani, S. R., \& Sunjoto, S. (2018). Analisis Implementasi Pembelajaran IPS Dalam Membentuk Karakter Nasionalisme Di Mts Miftahul Jannah Parakan Trenggalek. Islamic Counseling: Jurnal Bimbingan Konseling Islam.

https://doi.org/10.29240/jbk.v2i2.534

Habsy, B. A. (2017). Seni Memehami Penelitian Kuliatatif Dalam Bimbingan Dan Konseling: Studi Literatur. JURKAM: Jurnal Konseling Andi Matappa.

https://doi.org/10.31100/jurkam.v1i2.56

kusuma. (2007). pendidikan karakter. Grasindo.

Nadziroh, F. (2017). Analisa Efektifitas Sistem Pembelajaran. Jurnal Ilmu Komputer Dan Desain Komunikasi Visual (Jikdiskomvis).
Narwanti, S. (2014). PENDIDIKAN KARAKTER. relasi inti media.

Pranomo, swito eko. (2013). hakikat pendidikan ilmu pengetahuan sosial. widya karya.

tim sanggar pendidikan grasindo. (2010). membiasakan perilaku yang terpuji sebuah pengantar untuk pendidikan karakter. PT. Grasindo.

Wulandari, N., \& Vebrianto, R. (2017). Studi Literatur Pembelajaran Kimia Berbasis Masalah Ditinjau Dari Kemampuan Menggunakan Laboratorium Virtual. Seminar Nasional Teknologi Informasi, Komunikasi Dan Industri (SNTIK) 9.

Zuhud Ramdani, Z. (2015). Integrasi Pendidikan Karakter dalam Pembelajaran IPS di MTsN Model Selong Lombok Timur. SOCIA: Jurnal Ilmu-Ilmu Sosial. https://doi.org/10.21831/socia.v11i1.529 3 